\title{
Correlation of Hormone Receptors with Her-2 Neu Protein Expression and the Histological Grade in Invasive Breast Cancers in a Cohort of Saudi Arabia
}

\section{Suudi Arabistan'da İnvaziv Meme Kanserlerinde Her-2 Neu Protein Ekspresyonu ve Hormon Reseptörlerinin Illişkisi}

\author{
Maha ARAFAH \\ Department of Pathology, King Saud University, RIYADH, SAUDI ARABIA
}

\begin{abstract}
Objective: Data on Hormone Receptor and Her-2/neu expression in breast cancers from Saudi Arabia and Gulf Region is sparse. We undertook this study to describe the patterns of hormone receptor and Her-2/neu protein expression in breast carcinoma and compared them with the histological grade at a University Hospital in Riyadh.
\end{abstract}

Material and Method: We conducted a retrospective study on 164 invasive ductal carcinoma of breast between the year 2002 and 2008. Immunohistochemical analysis for Estrogen and Progesterone Receptor and Her-2/neu was done in all the cases. Fluorescent in situ hybridization for Her-2/neu gene amplification was performed in all $2+$ cases and few equivocal $1+$ and $3+$ case by immunohistochemistry. Correlation between Estrogen and Progesterone Receptor and Her-2/ neu amplification and grade of tumor was calculated.

Results: The expression of Estrogen Receptor, Progesterone Receptor were significantly correlated $(\mathrm{p}<0.001)$. Also, there was a significant negative correlation between expression of hormone receptor and Her-2/neu amplification. The histologic grade of the tumor was significantly correlated to the expression of both Estrogen and Progesterone Receptor. However, the relationship between Her-2/ neu amplification and grade was not significant and many of the grade III tumor were Her-2/neu negative. In addition, Her-2/neu gene amplification by fluorescent in situ hybridization was observed in $84.6 \%$ of breast cancer that were $3+$ and in $18.75 \%$ cases that were $2+$ by immunohistochemistry.

Conclusion: Prevalence of Estrogen and Progesterone Receptor expression and Her-2/neu amplification in breast cancer in the Saudi Arabian population is similar to that reported internationally. There is a negative correlation between hormone receptors expression and Her-2/neu amplification. However not all of the high-grade breast cancers showed Her-2/neu positive status.

Key Words: Breast neoplasms, Her-2/neu, Hormone receptors

\section{ÖZ}

Amaç: Suudi Arabistan ve Körfez bölgesinde meme kanserlerinde hormon reseptörleri ve Her-2/neu ekspresyonu ile ilgili veri azdır. Bu çalışmada, Riyad Üniversite Hastanesi’nde meme kanserlerinde hormon reseptörleri ve Her-2/neu ekspresyonu paternleri tanımlanmaktadır.

Gereç ve Yöntem: Retrospektif olarak, 2002-2008 yılları arasında tanı alan 164 invaziv duktal karsinom olgusu çalışılmıştır. İmmünohistokimyasal olarak östrojen ve progesteron reseptörü ve Her-2/neu çalışılmış, tüm 2+ olgular ve kuşkulu 1+ ve 3+ olguların bazılarında floresan in situ hibridizasyon yöntemi ile Her-2/ neu amplifikasyonu değerlendirilmiştir. Östrojen ve progesteron reseptörü ve Her-2/neu amplifikasyonu ile tümör derecesi ilişkisi değerlendirilmiştir.

Bulgular: Östrojen ve progesteron reseptörü ekspresyonu ilişkili saptanmıştır $(\mathrm{p}<0.001)$. Hormon reseptörleri ekspresyonu ile Her-2/neu arasında negatif ilişki gözlenmiştir. Histolojik derece östrojen ve progesteron reseptörü ekspresyonu ile anlamlı ilişki göstermektedir. Ancak, Her-2/neu amplifikasyonu ile derece arasında ilişki saptanmamıştır ve çoğu derece III tümörler Her-2/neu olumsuz bulunmuştur. Floresan in situ hibridizasyon ile meme kanserlerinin \%84.6's1 3+, \%18.75'i 2+ bulunmuştur.

Sonuç: Suudi Arabistan'da östrojen ve progesteron reseptörü ekspresyonu ve Her-2/neu amplifikasyonu oranları literatür ile benzerlik göstermektedir. Hormon reseptörü ekspresyonu ile Her-2/ neu amplifikasyonu ters ilişkilidir. Ancak, tüm yüksek dereceli meme kanserleri Her-2/neu ile pozitiflik göstermemektedir.

Anahtar Sözcükler: Meme tümörleri, Her-2/neu, Hormon reseptörleri

Correspondence: Maha ARAFAH

Department of Pathology, King Saud University, RIYADH, SAUDI ARABIA

E-mail:marafah@hotmail.com Phone: 4426022 


\section{INTRODUCTION}

Breast cancer is the commonest malignancy of females all over the world and the second leading cause of death due to malignancy among females. There is a variation in its incidence among multicultural populations, which suggests that etiological factors differ in their biological expression and impact on the disease outcome. The prognosis and management of breast cancer is influenced by classic variables as the histological type, grade and stage, status of Estrogen Receptor (ER), Progesterone Receptor (PR) and more recently, Her-2/neu status (1).

The expression of ER is seen in $70-80 \%$ cases and $\mathrm{PR}$ in $60-70 \%$ cases of invasive ductal carcinoma (2). These cases are associated with better outcome and good response to hormone therapy both in adjuvant and metastatic settings. Her/2 neu, also called C-erB-2, is a member of human epidermal growth factor family and encodes a transmembrane tyrosine kinase receptor. It is a proto oncogene that is located on chromosome 17, and amplified or the protein Her-2/neu over expressed in $15-25 \%$ cases of breast cancer (3). This marker has been extensively studied and it has been shown that Her-2/neu is a significant prognostic marker in both node positive and in node negative breast cancer patients (4). The positivity of Her$2 /$ neu in breast cancer is associated with high histological grade and tumor aggressiveness. It is thus assessed for both prognosis and prediction of response to trastuzumab treatment, chemotherapy and endocrine therapy.

For the last two decades, immunohistochemistry (IHC) has become the method of choice for ER and PR assessment. The most common cut off to define ER positivity is $10 \%$ but there is convincing data that patients with even $1 \%$ ER positive tumor cells benefit from hormone therapy (5). For Her-2/neu status, there is no agreement as to the best method of assessing amplification and over-expression as no standardised validated method exists for Her-2/neu testing. The Food and Drug Association (FDA) has approved Hercep test for IHC and Path Vysion for Fluorescent in situ hybridization (FISH). These are most commonly used methods for Her-2 /neu assessment nowadays as well as in our present study.

The aim of this study is to demonstrate the pattern of expression of hormone receptor and Her-2/neu in breast carcinoma, the correlation between histological grade of the lesion, ER and PR hormonal status, and Her-2 neu expression. Also, the equivocal cases for Her-2/neu expression by IHC will be resolved by FISH analysis.

\section{MATERIAL and METHODS}

This was a retrospective study. We studied 164 patients histologically confirmed as infiltrating ductal carcinoma of the breast, who underwent total mastectomy or lumpectomy with or without axillary dissection between 2002 and 2008 at King Khalid University Hospital. The formalin fixed, paraffin embedded 4-5 micrometer thick sections were stained by routine Haematoxylin and Eosin stain and the histological assessment for the grade was done using the modified criteria of Bloom \& Richardson Scoring System.

ER/PR analysis was carried out in all the164 cases according to manufactures instruction, as a routine procedure on a 4-micrometer sections of formalin-fixed, paraffin embedded tumor after microwave antigen retrieval (0.01M Citrate buffer $\mathrm{pH}$ 6.0), using commercially available mouse monoclonal antibodies to ER, PR (clone 6F11 and Clone 16 respectively, Ventana, Tucson, AZ). The staining for ER and PR was classified as positive if more than $10 \%$ of the tumor cells exhibited nuclear staining. Her-2/neu immunohistochemical analysis was done using Hercep test kit (clone CB11) according to the manufactures instruction and the results were interpreted as follows using the original FDA and new ASCO/CAP guideline recommendations (6). Scoring was done on a 0-3 scale. Positive $(3+)$ was defined as strong complete membranous staining in more than $30 \%$ of the tumor cell population. Borderline $(2+)$ was defined as moderate membranous staining in more than $10 \%$ of tumor cells. 1+ was defined as either weak or barely perceptible membranous staining in more than $10 \%$ of the tumor cells. 0 was completely negative staining or membranous staining in less than $10 \%$ of the tumor cells. Scores of 0 and $1+$ were considered as negative for Her-2/neu expression, $3+$ as immune-positive while $2+$ were weakly or borderline positive. Positive and negative controls were included in each batch.

FISH analysis was performed for Her-2 neu gene amplification in all $2+$ cases ( 32 cases) by IHC, and 28 equivocal cases of $1+$ and $3+$ (showing some technical fault as staining of the blood vessel or benign ducts) from the year 2005-2008. The cases were sent to Kassel Klinikum in Germany (as this test is not available in our institution) for further assessment by FISH analysis to confirm or exclude gene amplification. HER-2/neu gene amplification were determined by FISH according to Path Vysion (Vysis, Inc) in paraffin embedded tissue sections as a ratio of HER-2/ neu gene copies-to chromosome 17 centromere copies.

Statistical significance was set at $\mathrm{p} \leq 0.05$. Data was analyzed by chi square test. Computations were performed with the sigma STAT for windows software (version 2.03, SPSS, Inc. Chicago, IL).

\section{RESULTS}

Of the total 164 cases, 108 expressed ER, PR, or both (ninety two cases expressed both ER and PR, fourteen cases only ER, and two cases only PR positive) (Figures 1,2). 
Remaining 56 cases were both ER and PR negative. Patients were thus divided into following four groups: ER + PR+ (92/164, 56\%), ER+/PR- (14/164, 8.5\%), ER-/PR+ (2/164, $1.2 \%)$ \&ER-/PR- $(56 / 164,34.2 \%)$ as shown in Table I. A statistically significant correlation was found between the expression of ER and PR $(\mathrm{p}<0.001)$.

For Her-2neu expression by IHC, out of the total of 164 cases, 58 were $3+$ (Figure 3 ), 23 cases were $2+$ (Figure 4 ) and the remaining were either $1+$ or 0 . It was found that ER and PR expression was increased significantly in Her-2 negative tumors compared to Her-2 positive tumors. However, a substantial number of Her-2 positive tumors still expressed ER or PR (Table II). Thus there was a statistically significant negative correlation between the expression of hormone receptor and Her-2/neu over expression.

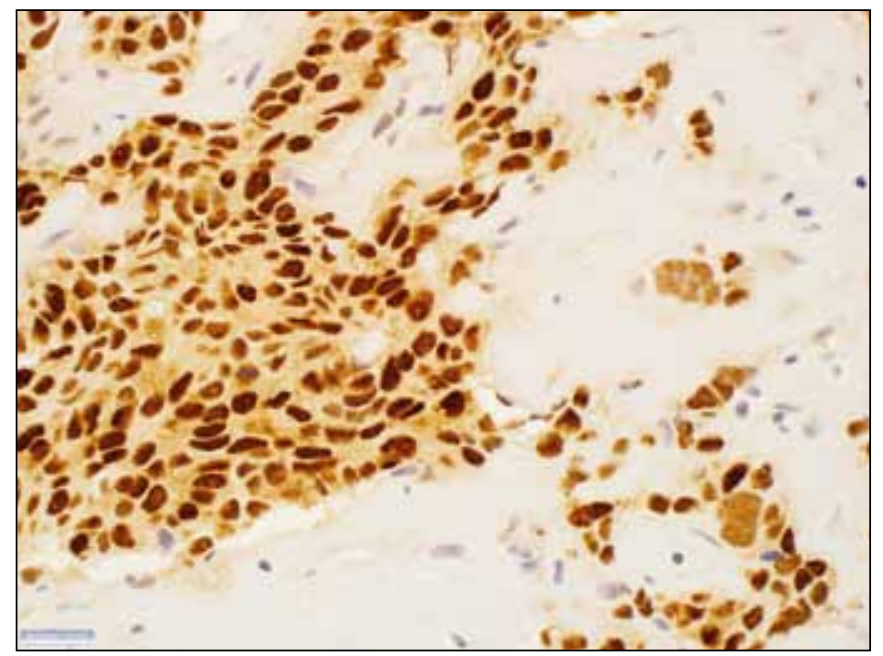

Figure 1: IHC showing Estrogen Receptor positive tumor cells in breast cancer (x400).

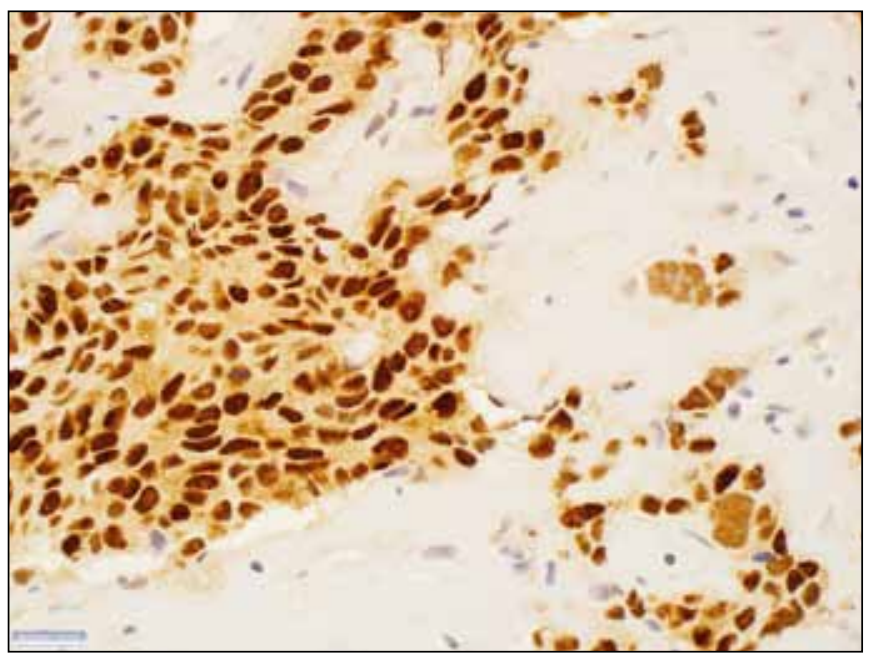

Figure 3: Her-2 immunostaining: strongly positive (3+) pattern showing intense membranous staining in more than $10 \%$ of the tumor cells (x600).
Out of 164 cases of invasive ductal carcinoma of breast, nine cases were grade I, eighty five cases were grade II and seventy cases were grade III. The reactivity for steroid receptors was observed to decrease with increasing grade. Grade II tumors expressed ER and PR more than grade III tumors (Table III). Thus the grade of tumor was significantly correlated to the expression of both ER and PR $(\mathrm{r}=6.085, \mathrm{p}=0.047$, and $\mathrm{r}=11.169, \mathrm{p}=0.025$, respectively). The relationship between Her-2/Neu over expression and grade of tumor was found to be not significant and vast majority of Her-2 negative tumors were grade III.

Sixty cases out of 164 , those were either $2+$ and few $1+$ or $3+$ were confirmed by FISH analysis (Table IV). The cases assigned by IHC as suspicious for 1+ (two cases) group were Her-2/Neu negative by FISH analysis. Among the

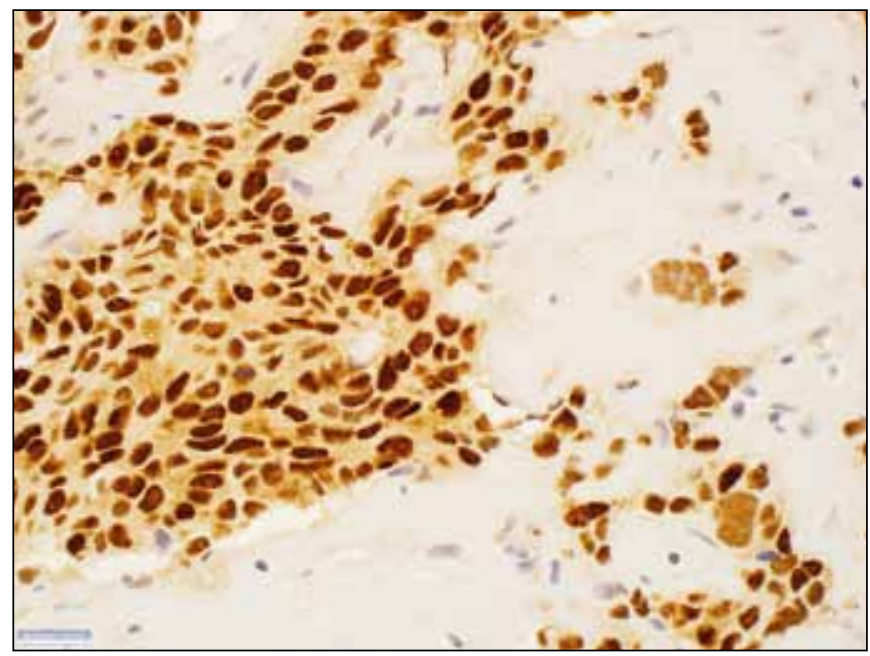

Figure 2: IHC showing Progesterone Receptor positive tumor cells in breast cancer $(\mathrm{x} 400)$.

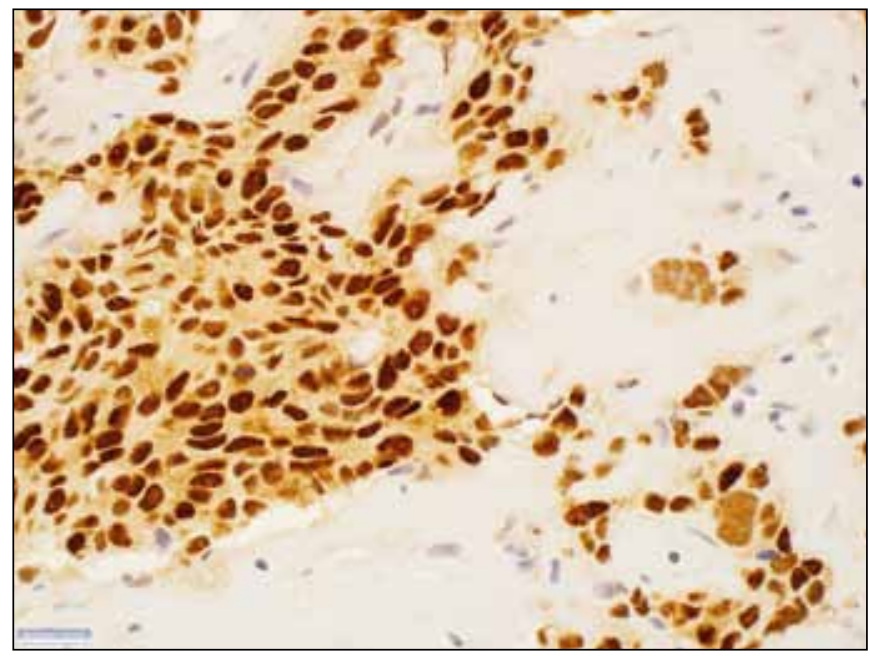

Figure 4: Her-2 immunostaining: Intermediate $(2+)$ pattern showing moderately complete membranous staining in more than $10 \%$ of the tumor cells (x600). 
samples described immunohistochemically as $2+(32$ cases), amplification of Her-2/Neu gene was discovered in $18.25 \%$ of cases $(n=6)$. The remaining $81.25 \%$ cases $(n=26)$ were negative by FISH method.

In the group of specimen assessed by IHC as equivocal for $3+$ (26 cases), Her-2/neu gene amplification was detected in $84.6 \%(n=22)$ of cases. Lack of gene amplification by FISH was seen in 4 cases $(15.3 \%)$.

\section{DISCUSSION}

ER, PR and Her-2/neu represent the most acceptable factors for predicting prognosis, response or resistance to treatment and the potential use of newer drugs such as trastuzumab in the case of Her-2/neu over expression.

We performed a retrospective study in a cohort of 164 patients to correlate hormone receptor and Her-2/neu status with histological grade of the lesion and ER, PR hormonal status. Consistent with most widely adapted clinical practice, and the practice at our institution, we considered a tumor as Her-2 positive as being either IHC score of $3+$ or FISH positive (ratio of more than or equal to 2.2 ).

Table I: Relationship between estrogen receptor and progesterone receptor

\begin{tabular}{|l|c|c|c|}
\hline & PR + & PR - & Total \\
\hline ER + & $92(56 \%)$ & $14(8.5 \%)$ & 106 \\
\hline ER - & $2(1.2 \%)$ & $56(34.2 \%)$ & 58 \\
\hline Total & 94 & 70 & 164 \\
\hline
\end{tabular}

Table II: Association between Her-2status and ER and PR expression

\begin{tabular}{|l|c|c|c|c|}
\hline & Her-2/Neu +3 & Her-2/Neu +2 & Her-2/ Neu Negative (Score of 1+ or 0) & Total \\
\hline ER+, PR+ & 22 & 26 & 44 & 92 \\
\hline ER+, PR- & 6 & 2 & 6 & 14 \\
\hline ER-, PR+ & 2 & 0 & 0 & 2 \\
\hline ER-, PR- & 28 & 4 & 24 & 56 \\
\hline Total & 58 & 32 & 74 & 164 \\
\hline
\end{tabular}

${ }^{\star}$ ER: Estrogen Receptor, PR: Progesterone Receptor, +: Positive, -: Negative

Table III: Relationship of tumor grade with hormone receptor expression and Her-2/neu amplification in infiltrating ductal carcinoma specimens

\begin{tabular}{|l|c|c|c|c|}
\hline & Score & Grade I $(\mathbf{n}=9)$ & Grade II $(\mathbf{n}=\mathbf{8 5})$ & Grade III $(\mathbf{n}=\mathbf{7 0})$ \\
\hline \multirow{3}{*}{ Her-2 neu } & $3+$ & 0 & 28 & 30 \\
\cline { 2 - 5 } & $2+$ & 1 & 18 & 5 \\
\cline { 2 - 5 } & $0 / 1+$ & 8 & 40 & 35 \\
\hline \multirow{3}{*}{ ER } & Negative & 1 & 25 & 32 \\
\cline { 2 - 5 } & Positive & 8 & 60 & 38 \\
\hline \multirow{2}{*}{ PR } & Negative & 2 & 31 & 36 \\
\cline { 2 - 5 } & Positive & 7 & 54 & 34 \\
\hline
\end{tabular}

Table IV: Comparison of Her-2 status determined by FISH and by immunohistochemistry

\begin{tabular}{|l|c|c|c|c|}
\hline & \multicolumn{3}{|c|}{ Immunohistochemical Scores of Her-2 neu } & \multirow{2}{*}{ Total } \\
\hline & $\mathbf{1 +}$ & $\mathbf{2 +}$ & $\mathbf{3 +}$ & $32(53.3 \%)$ \\
\hline FISH - (\%) & $2(100 \%)$ & $26(81.25 \%)$ & $4(15.3 \%)$ & $28(46.6 \%)$ \\
\hline FISH + (\%) & $0(0 \%)$ & $6(18.75 \%)$ & $22(84.6 \%)$ & $60(100 \%)$ \\
\hline Total & $2(100 \%)$ & $32(100 \%)$ & $26(100 \%)$ & \\
\hline
\end{tabular}


In our study, the prevalence of ER, PR expression and Her$2 /$ neu amplification were $64.6 \%, 57.3 \%$, and $35.3 \%$. These fall in ranges given in the English literature (7-10). ER and PR determination are established procedures in the routine management of patients of breast cancer, primarily as a predictive factor for response to therapeutic and adjuvant hormonal therapy (11-12). In the published literature, approximately $50 \%$ of the tumors are ER+, PR+, 25\% ER-, PR-, 20\% ER+ PR- and 5\% ER-, PR+ (13). Our study reports a lower proportion of ER+, PR- (8.5\%) and high proportion $(34.2 \%)$ of hormone receptors negative cases. Desai et al and Dutta et al also obtained a high incidence of steroid non-reactivity in breast cancer patient $(14,15)$. In general, in our study there was a statistically significant positive correlation between the expression of ER and PR, as reported by others $(8,16,17)$. This also abides by the theory of ER dependent PR synthesis (15).

The co-expression of hormone receptors with that of her-2/ neu is infrequent as previously reported. In our study, Her$2 /$ neu receptor revealed a significant inverse association with hormone receptor status. We found that ER and PR expression was increased significantly in Her2/neu negative tumors, compared to Her2/neu positive tumors. Similar results were shown in the previous studies $(7,8$, 18-20). The generally accepted inverse correlation between the expressions of hormone receptors and Her2/neu amplification is explained by hormone dependent down regulation of Her2/neu involving a complex molecular interaction as reviewed by Ciocca et al and as shown by in vitro studies $(18,19,21)$. This is one of the reasons why women who over express Her2/neu may be resistant to tamoxifen. However, as demonstrated in our study and by others, ER positive cases can have Her2/neu over expression/ amplification. Both ER and Her2/neu positive tumors have poorer disease free and overall survival than ER positive, Her2/neu negative tumors, suggesting that Her2/neu over expression may be better predictor of response to tamoxifen therapy than ER status alone (22).

The grade of tumor in our study was significantly correlated to the expression of both ER and PR ( $\mathrm{p}=0.04, \mathrm{p}=0.025$, respectively). The lower grade tumors showed a high ER and PR positivity, being similar to other studies $(8,23)$. The overexpression/amplification of Her2/neu in different histological grades of invasive ductal carcinoma of breast has been subject of interest. In our study, the relationship between Her2/neu amplification and grade of tumor was found to be not significant and vast majority of Her2 negative tumors were grade III. This is in contrast with previous studies which reported histologically high-grade tumors association with increased rate of $\mathrm{Her} 2 /$ neu overexpression $(20,24-26)$.
We confirmed the results of Her-2/neu protein and overexpression of all $2+$ and equivocal $1+$ and $3+$ cases on IHC, using FISH analysis in total of 60 cases. As only patients with Her2/neu protein over expression and/or gene amplification benefit from trastuzumab treatment, our aim was to identify those cases, using more accurate and reliable method (i.e. FISH). Our results indicate that IHC $2+$ group is characterised by high heterogeneity as only $18.75 \%$ cases showed Her-2/neu gene amplification. The samples described by IHC as 3+, amplification of Her-2/ neu gene were discovered in $84.6 \%$ cases by FISH analysis. These results are in accordance with many previous reports in the evaluation of Her-2/neu status of breast cancer using formalin fixed paraffin embedded specimen, which concluded high level of correlation between IHC 3+ staining and amplification detected by FISH (27-31).

In conclusion, the prevalence of ER, PR and Her-2/neu amplification among Saudi Arabia breast cancer patients is similar to the rest of the world. Also, there is a negative correlation between expression of hormone receptor and Her-2/neu expression. The lower grade of tumor is related to hormone receptor expression in accordance to that reported in the literature, however not all our high grade tumor were Her-2/neu positive.

\section{ACKNOWLEDGEMENT}

I thank Dr Shaesta Naseem Zaidi, MD for her assistance in the study and preparation of the manuscript. A special thanks to Rouch Company who supported performing the FISH analysis at Kassel Klinikum in Germany.

\section{REFERENCES}

1. Horita K, Yamaguchi A, Hirose K, Ishida M, Noriki S, Imamura Y, Fukuda M: Prognostic factors affecting disease-free survival rate following surgical resection of primary breast cancer. Eur J Histochem 2001, 45:73-84

2. Zafrani B, Aubriot MH, Mouret E, De Crémoux P, De Rycke Y, Nicolas A, Boudou E, Vincent-Salomon A, Magdelénat $\boldsymbol{H}$, Sastre-Garau $\boldsymbol{X}$ : High sensitivity and specificity of immunohistochemistry for the detection of hormone receptors in breast carcinoma: comparison with biochemical determination in a prospective study of 793 cases. Histopathology 2000, 37: 536-545

3. Hanna W, Kahn HJ, Trudeau M: Evaluation of HER-2/neu (erbB-2) status in breast cancer: from bench to bedside. Mod Pathol 1999, 12: 827-834

4. Ross JS, Fletcher JA: The HER-2/neu oncogene in breast cancer: prognostic factor, predictive factor, and target for therapy. Oncologist 1998, 3: 237-252

5. Hammond ME, Hayes DF, Dowsett M, Allred DC, Hagerty KL, Badve S, FitzgibbonsPL, Francis G, Goldstein NS, Hayes M, Hicks DG, Lester S, Love R, Mangu PB,McShane L, Miller K, Osborne CK, Paik S, Perlmutter J, Rhodes A, Sasano H,Schwartz JN, Sweep FC, Taube S, Torlakovic EE, Valenstein 
P, Viale G, Visscher D, Wheeler T, Williams RB, Wittliff $J L$, Wolff AC: American Society of Clinical Oncology/College of American Pathologists Guideline recommendations for immunohistochemical testing of estrogen and progesterone receptors in breast cancer. J Clin Oncol 2010, 28: 2784-2795

6. Brunelli M, Manfrin E, Martignoni G, Bersani S, Remo A, Reghellin D, Chilosi M, Bonetti F: HER-2/neu assessment in breast cancer using the original FDA and new ASCO/CAP guideline recommendations: impact on selecting patients for herceptin therapy. Am J Clin Pathol 2008, 129: 907-911

7. Huang HJ, Neven P, Drijkoningen M, Paridaens $R$, Wildiers $H$, Van Limbergen E, Berteloot P, Amant F, Vergote I, Christiaens MR: Hormone receptors do not predict the HER2/neu status in all age groups of women with an operable breast cancer. Ann Oncol 2005, 16: 1755-1761

8. Ratnatunga $N$, Liyanapathirana LV: Hormone receptor expression and Her/2neu amplification in breast carcinoma in a cohort of Sri Lankans. Ceylon Med J 2007, 52: 133-136

9. Perez EA, Pusztai L, Van de Vijver M: Improving patient care through molecular diagnostics. Semin Oncol 2004, 31:14-20

10. Piccart MJ, Mano M, Lohrisch C, Di Leo A: Herceptin for the treatment of breast cancer: what we know-and what we have yet to learn. Cancer Futures 2002, 1: 73-79

11. Bast RC Jr, Ravdin P, Hayes DF, Bates S, Fritsche H Jr, Jessup JM, Kemeny N, Locker GY, Mennel RG, Somerfield MR: American Society of Clinical Oncology Tumor Markers Expert Panel. 2000 update of recommendations for use of tumor markers in breast and colorectal cancer: clinical practice guidelines of American Society of Clinical Oncology. J Clin Oncol 2001, 19:1865-1878

12. Donegan WL: Tumor-related prognostic factors for breast cancer. CA Cancer J Clin 1997, 47: 28-51

13. Barnes DM, Millis RR: Oestrogen Receptors: the History, the Relevance and the Methods of Evaluation. In Kirkham N, Lemoine NR. (Eds): Progress In Pathology. Vol. 2. Edinburgh, Churchill Livingstone, 1995, 89-114

14. Desai SB, Moonim MT, Gill AK, Punia RS, Naresh KN, Chinoy RF: Hormone receptor status of breast cancer in India: a study of 798 tumors. Breast 2000, 9: 267-270

15. Dutta V, Chopra GS, Sahai K, Nema SK: Hormone receptors, Her-2/Neu and chromosomal aberrations in breast cancer. Medical Journal Armed Force India 2008, 64: 11-16

16. Horwitz KB, McGuire WL: Estrogen control of progesterone receptor induction in human breast cancer: role of nuclear estrogen receptor. Adv Exp Med Biol 1979, 117: 95-110

17. Grann VR, Troxel AB, Zojwalla NJ, Jacobson JS, Hershman D, Neugut AI: Hormone receptor status and survival in a populationbased cohort of patients with breast carcinoma. Cancer 2005, 103 : 2241-2251

18. Ciocca DR, Gago FE, Fanelli MA, Calderwood SK: Coexpression of steroid receptors (estrogen receptor alpha and/or progesterone receptors) and Her-2/neu: Clinical implications. J Steroid Biochem Mol Biol 2006, 102: 32-40
19. Konecny G, Pauletti G, Pegram M, Untch M, Dandekar S, Aguilar Z, Wilson C, Rong HM, Bauerfeind I, Felber M, Wang HJ, Beryt M, Seshadri R, Hepp H, Slamon DJ: Quantitative association between HER-2/neu and steroid hormone receptors in hormone receptor-positive primary breast cancer. J Natl Cancer Inst 2003, 95: 142-153

20. Ivkovic-Kapicl T, Knezevic-Usaj S, Djilas-Ivanovic D, Panjkovic M: Correlation of HER-2/neu protein overexpression with other prognostic and predictive factors in invasive ductal breast cancer. Vivo 2007, 21: 673-638

21. Ciocca DR, Fujimura FK, Tandon AK, Clark GM, Mark C, LeeChen GJ, Pounds GW, Vendely P, Owens MA, Pandian MR: Correlation of HER-2/neu amplification with expression and with other prognostic factors in 1103 breast cancers. J Natl Cancer Inst 1992, 84: 1279-1282

22. Ferrero-Poüs M, Hacène K, Bouchet C, Le Doussal V, TubianaHulin M, Spyratos F: Relationship between c-erbB-2 and other tumor characteristics in breast cancer prognosis. Clin Cancer Res 2000, 6: 4745-4754

23. Thoresen S, Thorsen T, Tangen M, Hartveit F: Oestrogen and progesterone receptor content and the distribution of histological grade in breast cancer. Breast Cancer Res Treat 1982, 2: 251-255

24. Hoff ER, Tubbs RR, Myles JL, Procop GW: HER2/neu amplification in breast cancer: stratification by tumor type and grade. Am J Clin Pathol 2002, 117: 916-921

25. Ariga R, Zarif A, Korasick J, Reddy V, Siziopikou K, Gattuso P: Correlation of her-2/neu gene amplification with other prognostic and predictive factors in female breast carcinoma. Breast J 2005, 11: $278-280$

26. Huang HJ, Neven P, Drijkoningen M, Paridaens $R$, Wildiers $H$, Van Limbergen E, Berteloot P, Amant F, Vergote I, Christiaens MR: Association between tumor characteristics and HER-2/neu by immunohistochemistry in 1362 women with primary operable breast cancer. J Clin Pathol 2005, 58: 611-616

27. Gramlich TL, Cohen C, Fritsch C, DeRose PB, Gansler T: Evaluation of c-erbB-2 amplification in breast carcinoma by differential polymerase chain reaction. Am J Clin Pathol 1994, 101: 493-499

28. Pauletti G, Godolphin W, Press MF, Slamon DJ: Detection and quantitation of HER-2/neu gene amplification in human breast cancer archival material using fluorescence in situ hybridization. Oncogene 1996, 13: 63-72

29. Persons DL, Borelli KA, Hsu PH: Quantitation of HER-2/neu and c-myc gene amplification in breast carcinoma using fluorescence in situ hybridization. Mod Pathol 1997, 10: 720-727

30. Jacobs TW, Gown AM, Yaziji H, Barnes MJ, Schnitt SJ: Comparison of fluorescence in situ hybridization and immunohistochemistry for the evaluation of HER-2/neu in breast cancer. J Clin Oncol 1999, 17: 1974-1982

31. Birner P, Oberhuber G, Stani J, Reithofer C, Samonigg $H$, Hausmaninger $H$, Kubista $E$, Kwasny W, KandiolerEckersberger D, Gnant M, Jakesz R: Austrian Breast \& Colorectal Cancer Study Group. Evaluation of the United States Food and Drug Administration-approved scoring and test system of HER2 protein expression in breast cancer. Clin Cancer Res 2001, 7: $1669-1675$ 